\title{
Dynamics and farmers strategies for small ruminant market in Egypt
}

\author{
Véronique Alary ${ }^{1 \star}$, Adel Aboul-Naga ${ }^{2}$, Mohamed El-Sheifa ${ }^{2}$, Nidal Abdelkrim ${ }^{1}$ and \\ Helmi Metawi ${ }^{2}$ \\ ${ }^{1}$ ICARDA, 15 G. Radwan Ibn El-Tabib St., Giza, Egypt, P. O. Box: 2416, Cairo, Egypt. \\ ${ }^{2}$ APRI, Nadi el Said St., Dokki, Giza, Egypt. \\ Accepted 6 December, 2011
}

\begin{abstract}
The main objective of the study was to identify the main driving factors of marketing strategies of farmers in link with the observations of change in the sheep and goat sector. A field survey on marketing strategies of small ruminants in Egypt was conducted in 2009 and 2010 at markets and farms' levels in different agro-ecological zones. The field data showed that breeders' market strategies had experienced important changes during the last decades due to different driving forces such as change in socioeconomic conditions of the producers and noticeable changes of consumption patterns. Sheep and goat activities are more and more considered as income diversification activities in the irrigated areas due to land fragmentation to face family needs. In the rainfed area, the marketing strategy of young males respond both at the increase of feed costs and the new demand from upper social class in the large towns and touristic areas. Unlike North African countries, Ramadan and Qurban Aïd periods might not constitute the main marketing period for small ruminants.
\end{abstract}

Key words: Small ruminant, marketing strategies, farming system, Egypt.

\section{INTRODUCTION}

A brief review of the sheep and goat production and trade in the region underlines the particular profile of Egypt in the region in regards to animal production systems (Alary, 2010). Although Egypt is well known for its large ruminants stock, the goat and sheep stocks recorded one of the highest annual growth rates compared to other Near East and North Africa countries (NENA) during the last decades. If sheep and goat (SR) constitute the main activity in the arid and semi arid areas, the national increase of SR population will occur mainly in the very vulnerable rural and peri urban households along the Nile valley. Does this development respond to the national economic and social demand? What are the main driving factors of marketing strategies of SR by breeders? Is this activity considered as an economic opportunity thanks to market demand?

Many research studies emphasize the positive role of

${ }^{*}$ Corresponding author. E-mail: veronique.alary@cirad.fr. Tel: (20) 1832651 44. Fax: (20) 235725099. markets to develop small holders in rural areas. Some authors (Peet and Watts, 1993; Tiffen et al., 1994) showed how the liberalization of markets can be a mechanism for generating price signals that orient and stimulate local investment and increase the well being of small farmers. But the role of markets can differ according to the environmental conditions of farmers and the nature of assets. For instance in dry land areas, livestock represent both a major marketable assets (Binswanger and McIntire, 1987) but also a major social capital in the sense of security (Scoones, 1989; Turner and Williams, 2002). And marketing strategies of livestock are more complex. Moreover Turner and Williams (2002) showed that the impact of livestock markets on household decisions is not led solely by the characteristics of supply and demand at the marketplace by the social institutions and wealth endowments that mediate livestock owners' access to markets.

The main objective of the study was to identify the main driving factors of marketing strategies of farmers in link with the observations of change in the sheep and goat sector. A field survey on marketing strategies of small 
Table 1. Annual growth rate of livestock populations in Egypt over the last two decades.

\begin{tabular}{lcc}
\hline Livestock & Annual growth rate 1988-1997 (\%) & Annual growth rate 1998-2007 (\%) \\
\hline Goats & 5.77 & 2.01 \\
Sheep & 0.87 & 2.42 \\
Cattle & 1.15 & 3.53 \\
Buffaloes & 2.31 & 2.36 \\
\hline
\end{tabular}

Source: FAOSTAT, 2007.

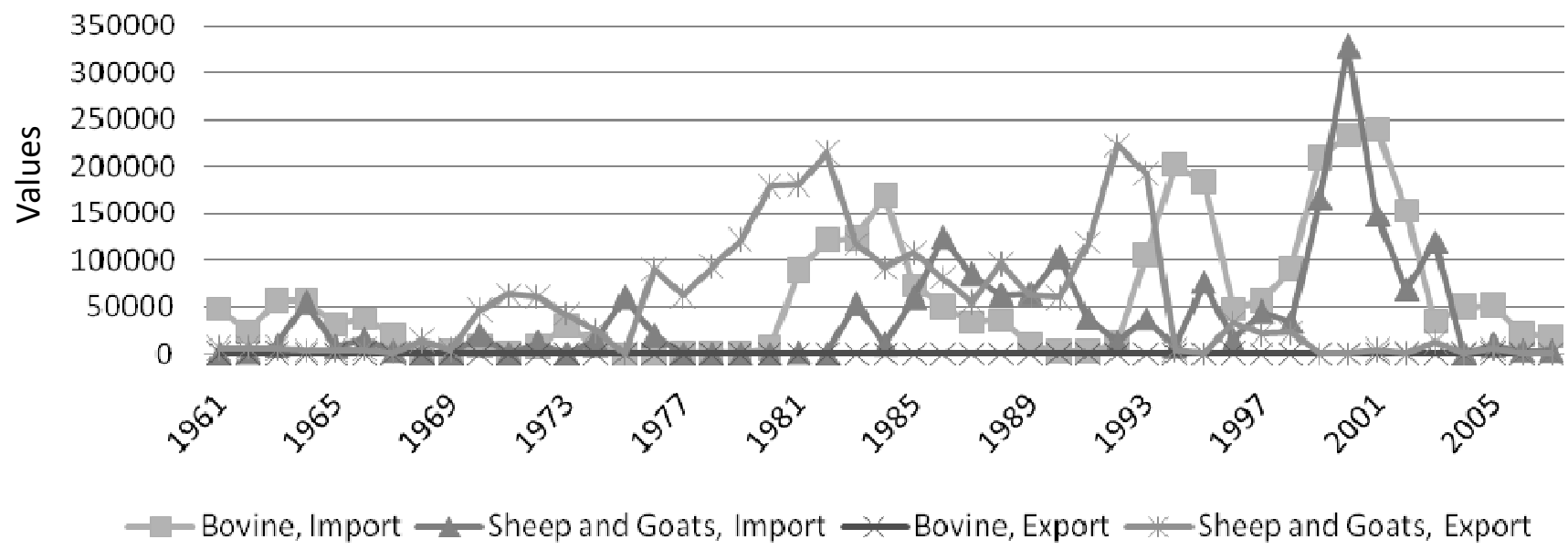

Figure 1. Trend of import and export of ruminant since the sixties in Egypt (FAOSTAT, 2007).

ruminants in Egypt was conducted in 2009 and 2010 at markets and farms' levels in different agro-ecological zones. The change on the sheep and goat market results from direct market observations and statistical analysis.

\section{Place of small ruminants in the livestock population and meat consumption}

Alary (2010) showed that small ruminant population represented around $50 \%$ of the total ruminant population in Egypt against more than $80 \%$ in the majority of the countries in the NENA countries in 2007. In the same time, Egypt recorded the highest annual growth rate of small ruminants' population during the last two decades in the North Africa. Table 1 shows that goat population recorded great animal increase from 1988 to 1997 compared to sheep, while in the recent years there is a sort of balance trend with between sheep and goat annual growth rate.

Sheep population showed its largest increase (3.1 to 5.3 million) during the period of 1995 to 2005, while number of goats increased from 3 to 4 million and cattle from 3 to 4.5 million during the same period. Around one third of the sheep and goat population is located in Upper Egypt. The second sheep populated region is West delta with $22.8 \%$ of the population and the Mid-Egypt for goat with $23.5 \%$ of the population (Economic Affairs Sector, 2007).

The international trade of ruminant shows that Egypt was a substantial exporter of small ruminant during the 70's and 90's and it became net importer over the last decade with a peak of around 320,000 heads in the beginning of the 21st century (Figure 1). This may be explained by the drought that affected the region by that time, but also due to the increase in meat demand with the population growth and the increase of the purchasing power of some social categories in the society.

The official slaughter rates in the abattoirs were estimated at 24.4 and $30.8 \%$, respectively for goat and sheep stocks in 2007 (FAOSTAT, 2007). These low rates of slaughtering could be explained by the multi-purpose roles of sheep and goat within the household-farming system. Sheep and goat provide domestic consumption, ensure social events and provide cash flow for family expenditure. Despite the Egyptian law prohibits home slaughtering, many herders practice it for family consumption, and some herders practice the slaughtering at home for selling, especially in rural areas.

Figure 2 shows great differences in the development of mutton, goat and poultry meat consumption in Egypt compared to the rest of NENA region. The contribution of mutton and goat consumption in the per capita meat consumption has decreased from 10 to $5 \%$ from 1961 to 


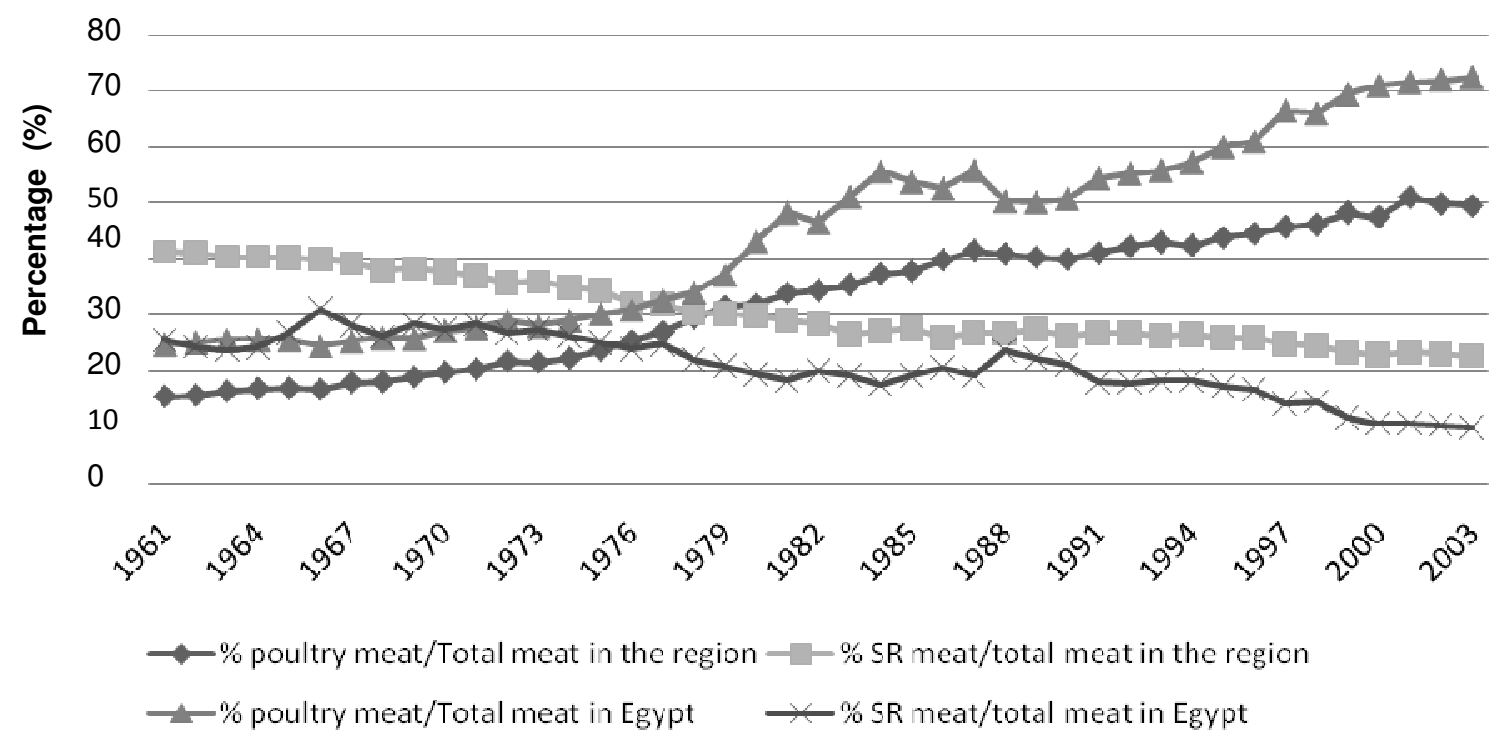

Figure 2. Contribution of small ruminants (SR) and poultry meat to the meat consumption in Egypt and in near East and North Africa (NENA) region; Source: FAOSTAT, 2007.

2003 (Galal, 2007). The per capita annual consumption of sheep and goat meat was estimated around $1.1 \mathrm{~kg}$ compared to $8.8 \mathrm{~kg}$ from bovine. These estimates didn't include the family self-consumption of mutton and goat meat that could change the consumption pattern, especially in the rural areas. According to Galal (2007), although mutton is considered as a traditional meat, it is also a seasonal consumed product during religious occasions and festivities. At the national level, daily per capita intake of animal protein is around $22.7 \mathrm{~g}$ from red meat, $28.0 \mathrm{~g}$ from milk, $26.1 \mathrm{~g}$ from fish and $18 \mathrm{~g}$ from poultry meat.

While the official statistics shows an increase in sheep and goat stocks, the Egyptians become more and more dependent on poultry meat in their food. The main reasons would be the lower price of poultry meat and availability in every retail shops. However, the increase of sheep and goat population needs some investigations in link with the markets and the farming strategy.

\section{MATERIALS AND METHODS}

Preliminary market surveys were conducted during the Qurban Aïd period in 2009 based on qualitative interviews among farmers, traders and butchers to analyze the changes in the demand and supply related to sheep and goat. This has been followed by farm surveys in three agro-ecological zones in Egypt: oasis region in the New Valley, rainfed area in Matruh region and Nile Valley irrigated area in the Sohag governorate (Figure 3).

\section{Qurban aïd market survey}

Preliminary market survey were organized in November 2009 (three to two weeks before Qurban Aïd) to study the small ruminants marketing transactions during the festive period. The survey was mainly based on qualitative questions to assess sheep and goat markets and the main factors controlling the demand (who? when? What?), and the changes perceived. The questioners were herders, traders and butchers although the traders and butchers are commonly herders.

The study was conducted in three markets according to the proximity of Cairo and the dominant agriculture-livestock systems in the zone: Mazghona market near Cairo capital, Zefta market in Gharebi governorate at Mid-delta and El-Hamman market in rainfed Matruh governorate. 31 interviews were conducted. The study also allowed interviewing farmers and discussing about their sheep and goat farming activities and marketing strategies during Qurban Aïd and the rest of the year, and the main criteria for buying or selling animals, and the fattening activity.

\section{Farm survey}

During the year 2010, three farm surveys were organized among a stratified sample of 90 farms in three agro-ecological zones: the rainfed dry area of Matruh, the intensive agriculture region of Sohag in Upper Egypt and the Oasis region in New Valley (Figure 3). The three zones are representative of the two main farm systems in Egypt:

1. The rainfed production system: a complex system based on livestock, annual crops (mainly barley), tree, and off farm jobs. This system is well developed by traditional farmers and Bedouins in North coastal zones such as Matruh region. The SR stock in the North West Coastal Zone of Egypt represents some 8 to $10 \%$ of the national stock.

2. The irrigated production system: the typical mixed agriculturelivestock system that represents the majority of farms in the Delta and Nile Valley (around $76 \%$ of farming systems in Egypt). The feeding system is based on berseem, green corn and external feedstuff and concentrates.

The irrigated production systems are represented by two contrasted zones in our sample: the New Valley in the desert and Nile valley in Upper Egypt. The oasis context is characteristic of remote areas and Sohag has been chosen in link with its poverty ratio. More than $26 \%$ of the population will be below the poverty line. A stratified 


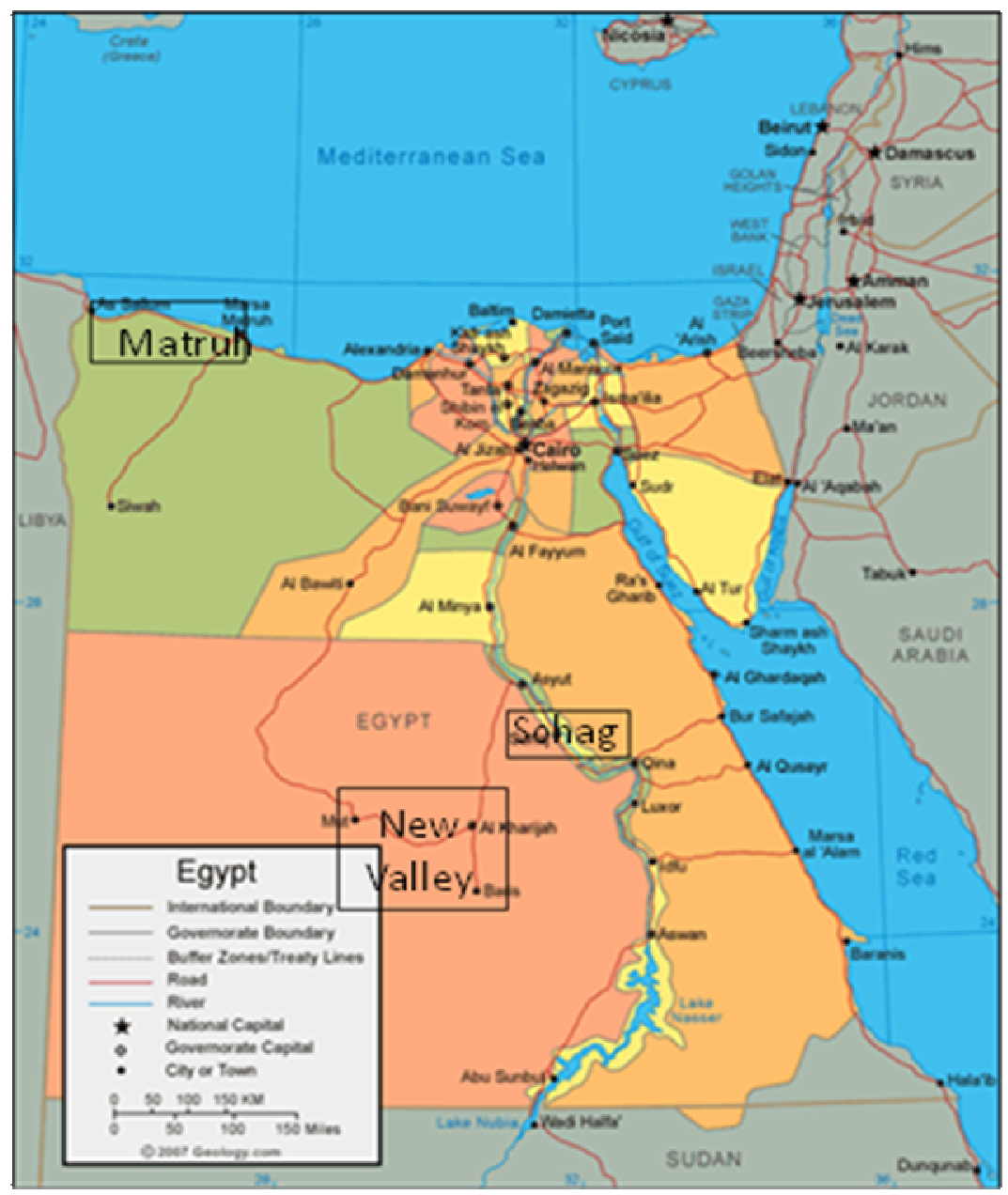

Figure 3. The three locations surveyed in Egypt.

sample was utilised based on two hierarchical criteria: (i) the location of the villages (their distance and access to the main city), and (ii) the flock size. With the agriculture land scarcity in the New Valley, landless farmers were also surveyed. Thirty farmers were surveyed in each agro-ecological zone.

The questionnaire was based on three components: 1. Farm and family information; 2. Agriculture-livestock activities: cropping and pasture lands, livestock system, off-farm activities, and farm facilities; and 3. Risk and poverty perception. The livestock system comprised information on herd structure, fattening practice, marketing strategy, feeding and other expenditure (labor, veterinary costs), etc.

\section{RESULTS}

\section{Market survey}

Table 2 synthesizes data relative to the three markets visited during Qurban Aïd 2009. In Mazghona and Zefta markets, the main demand came from butchers and consumers during the feast period; these markets can be considered as terminal markets. The prices had registered an increase compared to the last year (4.6
US $\$ / \mathrm{kg}$ in 2009 compared to $4.1 \mathrm{US} \$ / \mathrm{kg}$ in 2008). This increase was mainly related to the increase in feed prices. In Zefta market, some herders reported increase in red meat consumption with a preference for goat meat in substitution to poultry meat during the Avian Flu period. In El-Hamman market (Matruh Governorate), the demand was more diversified; there was the highest demand for young animals by the upper social class in nearby Alexandria city or for fattening in Delta region. The average price of live sheep decreased by $9 \%$ compared to the last year (established at $4.6 \mathrm{US} \$ / \mathrm{kg}$ ). This decrease was explained by decrease in the purchasing power of buyers and by the competition from other animals coming from out the region and due to the increase in numbers of small traders in the market.

Trading activities during Qurban Aïd provided complement income for small traders that are often breeders, while it was a full time activity for large ones. The first ones went to the market two or three times a week, and up to 8 times per week for large traders. Generally, the traders are not specialized in any animal species. In each market small traders dealt with less than 
Table 2. Main characteristics of markets visited during Qurban Aïd period, Egypt, 2009.

\begin{tabular}{|c|c|c|}
\hline Markets & Governorate & Description of the market \\
\hline \multirow{5}{*}{ Mazghona } & \multirow{5}{*}{ Giza } & Governorate attached to Cairo \\
\hline & & Held once a week \\
\hline & & Types of animals: sheep, goat, cattle, buffaloes and camels \\
\hline & & Main sellers: traders who are also herders \\
\hline & & Main buyers: butchers due to the proximity of Cairo \\
\hline \multirow{5}{*}{ Zefta } & \multirow{5}{*}{ Gharbia } & $120 \mathrm{~km}$ from Cairo in the Mid-Delta \\
\hline & & One a week \\
\hline & & Types of animals: sheep, goat, cattle and buffaloes \\
\hline & & Main sellers: herders and traders \\
\hline & & Main buyers: butchers, keepers and consumers \\
\hline \multirow{5}{*}{ El-Hamman } & \multirow{5}{*}{ Matruh } & $280 \mathrm{~km}$ from Cairo and $60 \mathrm{~km}$ West of Alexandria \\
\hline & & Once a week \\
\hline & & All types of animals but mainly sheep and goat \\
\hline & & Main sellers: herders \\
\hline & & Main buyers: traders, butchers and consumers \\
\hline
\end{tabular}

Table 3. Estimated profit margins from fattening activity of young lambs at Mazghona market, Egypt (in US $\$ /$ head and $\%$ of the selling price).

\begin{tabular}{lcccc}
\hline & Low margin system & \multicolumn{2}{c}{ High margin system } \\
\hline Purchasing price (around 4 months old) & 101.5 US\$ & $50.0 \%$ & 73.8 US\$ & $36.4 \%$ \\
Feed cost & 83.1 US\$ & $40.9 \%$ & 73.8 US\$ & $36.4 \%$ \\
Transport cost & 1.8 US\$ & $0.9 \%$ & 1.8 US\$ & $0.9 \%$ \\
Selling price (around 12 months) & 203 US\$ & & 221.5 US\$ & \\
Profit margin & 16.6 US\$ & $8.2 \%$ & 72.1 US\$ & $35.4 \%$ \\
\hline
\end{tabular}

10 small ruminants for Qurban Aïd compared to 20 small ruminants and around 30 large ruminants for large traders. Some of them sold directly to the restaurants. These traders practiced also fattening based on cut and carry clover plus concentrates for 5 months or on cereal and clover hay for 3 months. Profit margins varied according to the purchasing price of the lambs and then their age. Feed costs explained 70 to $90 \%$ of the profit margin (Table 3).

This increase of the number of small traders created a strong competition on the market. These small traders targeted directly consumers and butchers. In the Matruh region, this competition knew a peak in 2009 due to the low supply of animals in the markets. After fifteen dry years, farmers sold animals only to cover high feed costs.

On the retail side, two categories of butchers were distinguished. The first had a settled location where they sold their meat. They went to the market 2 to 3 times a week to buy around 5 sheep and 3 calves daily during Aïd period and 1 sheep and 1 calf per day out of Aïd period. They utilized the service of slaughterhouse; the prices were 3.7 US $\$ /$ sheep and 5.9 US $\$ /$ calf. The price of special cuts were around 7.7 US\$/kg during Qurban Aïd and 4.0 US $\$$ during the rest of the year. The second category can be classified as casual butchers. Slaughter and selling activities took usually place at the farm. They were breeders, but they do trading and butchering. Their activity depended on the demand from the neighbourhood and did not exceed 15 to 20 sheep during Qurban Aïd. Their profit margin was around $0.4 \mathrm{US} \$ / \mathrm{kg}$ for live animal. Body weight was one of the main criteria for buying, followed by animal conditions. According to the butchers the main criteria for chosen were the breed (animals with small fat tail), the body weight and the body conformation.

\section{Farm survey}

Table 4 show diverse situations in regards to sheep marketing strategies. In Matruh, the majority of herders went to the market once a week. Twenty percent of them 
Table 4. Indicators of marketing strategies at farm level in the three studied regions (Survey: 90 farmers, 2010).

\begin{tabular}{lccc}
\hline Criteria & Matruh & Sohag & New valley \\
\hline Percentage of farmers that expand their sheep and goat stocks & $6.7 \%$ & $23.3 \%$ & NA \\
& & & NA \\
Average purchasing price of sheep (US\$/head) & 94 & 118 & \\
& & & \\
Ramadam and Qurban Aïd period & $10.7 \%$ & $26.7 \%$ & $75.0 \%$ \\
Percentage of farmers who sold their animals & 163 & 241 & $145^{*}$ \\
Selling price of sheep (US $\$$ /head) & & & \\
& & & \\
Rest of the year & $64.3 \%$ & $40 \%$ & $62.5 \%$ \\
Percentage of farmers who sold their animals & 113 & 131 & $145^{*}$ \\
Selling price of sheep (US $\$$ head) & & & \\
Domestic consumption: & 1.4 & 2.3 & 5 \\
Number of sheep / year / family & 3.3 & 3.4 & 4.7 \\
Number of goat / year / family & 14.6 & 12.7 & 13.6 \\
Number of persons / family & & & \\
\hline
\end{tabular}

NA: No data available; ${ }^{*}$ this price is not specific to different periods.

sold their animals to intermediaries at the farm gate. They were mainly large herders with an average of more than 150 sheep. Markets are generally social places where farmers meet, exchange information and do business. Number of animals was an important factor in selling at the market or at farm gate, to avoid market risks and to reduce transportation costs. The year of the study (April 2009 to April 2010) was a dry year that followed 15 previous bad years in terms of precipitations. The majority of herders followed a strategy to maintain their animal stocks. They sold only some animals to cover family expenditures, feed stuff, and to reimburse loans or to renew a credit to traders. Only $10 \%$ of herders sold their animals during Qurban Aïd. The high price at that period was not a sufficient incentive to sell animals; most of the herders preferred keeping animals when the prices were high to increase their capital assets.

In Sohag Governorate, $40 \%$ of the herders sold directly at the market or at the farm, where $60 \%$ sold to intermediaries or to butchers at the farm gate. During the last year, $23 \%$ of them bought sheep or goat with an average price of 220 US\$ per animal. Nearby $40 \%$ of sheep herders sold animals out of Aid, $26.6 \%$ during Qurban Aïd, the rest kept their animals for self consumption or increasing their stocks. Price for sheep in Sohag governorate was noticeable attractive compared to the other two regions.

In the New valley, farmers sold their sheep and goat at farm gate to traders from the same village. Contrary to Matruh and Sohag, more than $50 \%$ of the herders sold their animals all the year, while $25 \%$ sold only during Qurban Aïd and 12.5\% the rest of the year. The rest kept their animals for family self-consumption or increasing their stock.
The family self-consumption of sheep meat varied between the three zones. It was the lowest in the pastoral areas of Matruh and the highest in the New Valley. However similar levels of self-consumption of goat meat were found in the three regions. These data don't include the purchased meat that can modify consequently the profiles of meat consumption in the different rural areas.

Fattening activities were relatively more practiced in Matruh (Table 5), although the feed cost was higher (due to the distance of the main feed sources), and the bad climatic conditions during the last years. In Sohag district, sheep fattening were not strategic at the farm level.

\section{DISCUSSION}

Mazghona and Zefta are mainly terminal markets to provide meat to butchers or consumers in the nearby cities, while El Hammam in Matruh is considered as a secondary market where animals are sold to others traders and breeders. This explains the wide range of types of animals in El-Hamman market to respond to different demands from traders, butchers and consumers. Contrary to Zefta with its local demands, Mazghona market is influenced by the large Cairo demand which explains high prices in the market compared to both El Hammam and Zefta makets. Mazgona market shows also a more competitive situation due to the flow of animals from Upper Egypt.

Then if feed cost is often cited as one of the main factors that influence market prices, demand seems to be strong factor on this regard. According to the interviews, the demand causes important dynamics in the markets; however, it is difficult to detect its trend due to 
Table 5. Technical and economic options of livestock farming activity in the three regions (Survey: 90 farmers, 2010).

\begin{tabular}{lccc}
\hline Parameter & Matruh & Sohag & New valley \\
\hline Number of farms & 28 & 15 & 24 \\
& & & \\
Average flock size (heads) & 104 & 12 & 47 \\
& & & \\
Fodder indicators: & $0 \%$ & $56 \%$ & $54 \%$ \\
Fodder crop/cropped area (in \%) & $\mathrm{NA}$ & 95 & 79 \\
Fertilizer cost for fodders (in US\$/feddan) & & & \\
& & & \\
Sheep fattening practice: & $42.9 \%$ & $33.3 \%$ & $20.8 \%$ \\
Percentage of farms which fatten their lambs & 2.5 & $\mathrm{NA}$ & 2.5 \\
Fattening period (months) & & & \\
& & & \\
Feed cost: & 0.54 & $\mathrm{NA}$ & 0.43 \\
Fattening cost (US $\$$ /head/day) & 0.4 & 0.23 & 0.19 \\
Non fattening cost (US\$/head/day) & &
\end{tabular}

NA: No data available.

contradictory signals through the market. In Mazghona market, an important market for Cairo supply, the demand on calves for Qurban Aïd period increased highly compared to mutton. In Mid-Delta, there was an increase in the demand on goat meat in substitution of poultry meat. In Matruh region (El-Hamman), the demand on young lambs is raising. The young animals go through two chains: (i) short one to restaurants and butchers with increasing demand due to the tourism development in the region and the consumption pattern from the upper and medium social classes in the near Alexandria city; and (ii) long one to intermediaries for the different objectives: breeding, fattening and marketing.

Although feed cost is not the only factor controlling selling price, it is the main operational costs for the herders. The farm survey showed that the concentrates represented between 25 and $40 \%$ of the selling price for fattening and more than $50 \%$ for growing. These feed costs did not include costs of roughage and fodder production. Ahmed et al. (2000) reported that feed cost represents $78 \%$ of operational costs in sheep farming. The feed cost will explain the recent marketing strategies of breeders in Matruh region. In this region, it is observed significant changes in sheep fattening and marketing practices over the last fifteen years, notably the reduction of fattening activities (although it remains more important compared to the other two areas), and the involvement of breeders in the trading activities to complement their farm income. But the marketing strategies of farmers in this zone differ with the size of the flock and life style (transhumance or settlement). In pastoral and agropastoral areas in the western part of North West Coastal zone, the marketing strategy remains mainly related to the climatic conditions as shown by Turner and Williams
(2002).

If body weight and conditions dominate the price negotiation between herders and traders, other criteria that determine the price is the breed; butchers have specific demands in regard to breed which related to fat distribution in the carcass (leanly), that is, light fat tail, some inter-abdominal but light inter and intra muscular fat. This explains that the dominant breed remains the Barki (means local breed).

The field study show also the development of sheep and goat productions in the rural household systems in highly populated regions such as Zefta in the mid-Delta and in the highest poverty regions in the country. In Sohag, $24 \%$ of the population are below the poverty line compared to $19.6 \%$ in the country and, with land fragmentation, it is a way to diversify the farm revenue for the small holders. There is also a trend to invest in small ruminants in the New Valley by governmental employers in order to complement their income. In Matruh the development of the small ruminant activity is in link with climatic conditions; sheep and goat are well known for their high adaptability to harsh climatic conditions as it had already been shown by McDowell and Woodward (1982) and Haelein (2001). In summary, in the three locations, sheep and goat constitute one way to reduce vulnerability and reduce poverty due to land fragmentation in Sohag, to location isolation in New Valley, and to harsh climatic conditions in Matruh. This explains why marketing strategies do not respond only to market signals.

The family self-consumption of small ruminant, especially goats, was the highest in New Valley followed by Matruh. In Sohag, small ruminant activity was in phase of capitalization. The domestic consumption of goat 
reveals the important role of goat in rural food security. This is in line with many studies on the roles of goat at the family level (Peacock, 2005; De Vries, 2008; Haenlin, 1998). Besides, the family self consumption of sheep answer more to social need than nutritional needs; the consumption occurs during family or religious ceremonies although marketing decisions answer to economic needs.

\section{Conclusion}

If feed cost is often cited as one of the main factors that influence market prices, there is also important qualitative and quantitative changes of meat consumption over the last two decades due to economic development, changes of food habits with urbanization and modernization, and the recent sanitary crisis and also risk perception of international crisis (BSE crisis, Avian Flu, Swine flu, etc.). Therefore the price increase in the markets reflects also an increase in the demand on sheep and goat meat with the population growth and the development of social classes with specific demand. The present data don't allow analysing the differentiated impacts of feed costs and change of consumption trend on the prices, which requires a deepest study on the market dynamics and a significant sample of consumers; but the study showed the importance of these two factors in the marketing strategies of breeders.

Finally, the survey reveals also various marketing strategies according to agro-ecological conditions, geographical situation (and proximity of cities), and land and demographic pressure which may explain the different roles of sheep and goat at the farm and national level in terms of poverty reduction and vulnerability and family food security at short and medium terms. Moreover, the present data show a different profile of small ruminant farming system compared to the rest of North Africa where the majority of herders are mainly oriented to the demand of sheep during Ramadan and Qurban Aïd periods (Alary and Boutonnet, 2007). Finally, the consumption pattern records important changes since the last decade, that seems to influence the farm activity. Price is often socially-biased reflecting the differential access and powers within local markets (Turner and Williams, 2002). The present investigation confirm the importance of social factors on the studied markets, the small herders and traders have their influences on the prices and transactions in the markets. If agricultural policies on feed prices can relieve the cash flow of herders, these policies will be insufficient to influence market supply and demand that depend on multi factors including the living conditions of famers and their family and the meat demand.

\section{ACKNOWLEDGEMENTS}

This research work took place in the framework of a collaborative research program between APRI, CIRAD and ICARDA on: "Resource management, access to market as ways to reduce the vulnerability: the case of Small Ruminant systems". This research benefited from the fund support of BLAFE (Bureau de Liaison Agricole Franco-Egyptien) and CIRAD.

\section{REFERENCES}

Ahmed AM, Abou-Bakr S, Sadek RR, Abdel-Aziz AS (2000). Appraisal of the current crop/livestock production system in a new reclaimed area operated by university graduates in Egypt. Proceeding $3^{\text {rd }}$ All Africa Conf. Anim. Agric. and 11th Conf. Egyptian Soc. Anim. Prod., Alexandria, Egypt, 6-9 November 2000, pp. 629-633.

Alary V, Boutonnet JP (2007). L'élevage ovin dans l'économie des pays du Maghreb... Un secteur en pleine évolution. Sécheresse, 17(1-2): 40-46

Alary V (2010). From a desk and Field Review on Small Ruminant System research in Egypt to recommendations for the development of joint research axes within the program: "Resource management, access to market as ways to reduce the vulnerability: the case of Small Ruminant systems", BLAFE REPORT, Technical assistance in the field of research on sustainability of small Ruminant Systems, 2010, CIRAD, ICARDA, APRI: Cairo, Egypt, 62 pp.

Binswanger HP, McIntire J (1987). Behavioural and material determinants of production relations in land abundant tropical agriculture. Econ. Dev. Cult. Change, 36(1): 73-100.

De Vries J (2008). Goats for the poor: Some keys to successful promotion of goat production among the poor. Small Rumin. Res., 77 (2008): 221-224.

Economic Affairs Sector (2009). Statistics of livestock, poultry, municipality and production fish statistics- Year 2007. Volume (13). Ministry of Agriculture and Land reclamation, Egypt.

FAOSTAT (2007). www. http://faostat.fao.org/default.aspx.

Galal S (2007). Farm animal genetic resources in Egypt: fact sheet. Egyptian J. Anim. Prod., pp. 1-23.

Haenlein GFW (1998). The Value of goats and sheep to sustain mountain farmers. Int. J. Anim. Sci., 13: 187-194.

Haenlein GFW (2001). Past, present and future perspectives of small ruminant dairy research. J. Dairy Sci., 84: 2097-2115.

McDowell RE, Woodward A (1982). Concepts in animal adaptation. Comparative suitability of goats, sheep, and cattle to tropical environments. In Ayers JL, Foote WC (eds) Proc. $3^{\text {rd }}$ Int. Conf. Goat and Disease, Dairy Goat Journal Publishers Co., Scottsdale, AR, pp. 387-393.

Peacock C (2005). Goats- A pathway out of poverty. Small Rumin. Res., 60: 179-186

Peet R, Watts M (1993). Introduction: development theory and environment in an age of market triumphalism. Econ. Geogr., 69(3): 227-253.

Tiffen M, Mortimore M, Gichuki F (1994). More people: Less erosion. Environmental recovery in Kenya. New York: John Wiley and Sons.

Turner MD, Williams TO (2002). Livestock market dynamics and local vulnerabilities in the Sahel. World Dev., 30(4): 683-705. 